Historia Slavorum Occidentis

2020, $\mathrm{nr} 1$ (24)

ISSN 2084-1213

DOI: $10.15804 /$ hso200104

Mągorzata Delimata-Proch (Poznań)

ORCID 0000-0002-7894-2589

\title{
Dziecięce choroby i urazy w świetle Skarbu Nieprzebranego Dobrodzieystw Boskich Jana Kazimierza Steczewicza (lata sześćdziesiąte i siedemdziesiąte XVII w.)
}

Słowa kluczowe: dzieci, choroby, wypadki, Jan Kazimierz Steczewicz, Matka Boża Rokitniańska

Keywords: children, diseases, accidents, Jan Kazimierz Steczewicz, Our Lady of Rokitno

Abstract: Skarb Nieprzebrany Dobrodzieystw Boskich by Jan Kazimierz Steczewicz provides an opportunity of analysing children's health and the consequences of unfortunate accidents. It also allows to take a closer look at the votive practices and rites described in the book of miracles.

Sytuacja dziecka w Polsce w różnych epokach od dekad cieszy się zainteresowaniem badaczy. Mimo to wciąż zauważalny jest niedostatek badań szczegółowych ${ }^{1}$. Za to wiele ksiąg cudów i łask w ogóle nie znalazło się w polu widzenia historyków. Czas

1 Np. D. Żołądź-Strzelczyk, Dziecko w dawnej Polsce, Poznań 2002; M. Delimata, Dziecko $w$ Polsce średniowiecznej, Poznań 2004; A. Bołdyrew, Matka i dziecko w rodzinie polskiej. Ewolucja modelu życia rodzinnego w latach 1795-1918, Warszawa 2008; D. Żołądź-Strzelczyk, K. Kabacińska-Łuczak, Codzienność dziecięca opisana słowem i obrazem. Życie dziecka na ziemiach polskich od XVI do XVIII wieku, Warszawa 2012; W kręgu rodziny epok dawnych. Dzieciństwo, red. B. Popiołek, A. Chłosta-Sikorska, M. Gadocha, Warszawa 2014; jeśli chodzi o przykłady artykułów i przyczynków, to wystarczy wskazać ostatnią publikację oraz bibliografię wymienionych prac. 
ku temu, aby uzupełnić (czy raczej uzupełniać, gdyż powinien to być proces) te braki i tak próbę wypełnienia luk z tych dwóch pól badawczych stanowi niniejszy tekst. Wpisuje się on w nurt badań szczegółowych, które w przyszłości powinny zaowocować syntezami w następujących obszarach: 1. kondycja zdrowotna dzieci lub sytuacja dziecka w ogóle, 2 . historia medycyny, 3. badania nad religijnością pielgrzymów i ruchem pielgrzymkowym.

Celem tego tekstu jest analiza przypadków dziecięcych opisanych w Skarbie Nieprzebranym Dobrodziejstw Boskich. Obrazie Cudownym Naświętszey Panny Mariey w Opactwie Bledzewskim Rokitnickiey Jana Kazimierza Steczewicza ${ }^{2}$. Zagadnienia, które poddałam analizie, to: liczba przypadków dziecięcych zebranych w tej księdze cudów i łask ${ }^{3}$. Tym szacunkowym obliczeniom towarzyszą pytania o: wiek i płeć dzieci, o choroby, na które zapadały i nieszczęśliwe zdarzenia, którym ulegały. Poza tym warto przyjrzeć się relacjom łączącym rodziców z dziećmi. J.K. Steczewicz zasygnalizował trwałość więzi, wspominając o zaangażowaniu matek i ojców w ratowanie potomstwa, a także w gesty wotywne. Same gesty proszalne i dziękczynne, ryty rewitalizacyjne również stanowią przedmiot tej refleksji; podobnie jak procedury medyczne, ewentualne terapie, jeśli J.K. Steczewicz takowe w ogóle odnotował.

Z cudownym obrazem z Rokitna są ściśle związane: historia cystersów z Bledzewa oraz dzieje sanktuarium w Rokitnie. Nie będę ich w tym miejscu omawiać, ponieważ jest to zagadnienie poboczne względem tej refleksji. Dodam jedynie, że dzieje zarówno klasztoru w Bledzewie, jak i kościoła w Rokitnie przedstawiono obszernie np. w monografii, która ukazała się w 2009 r. ${ }^{4} \mathrm{~W}$ tej samej publikacji naświetlono historię obrazu Matki Bożej Rokitniańskiej, który został namalowany na początku XVI w. Kto był autorem? Nie wiadomo. Prawdopodobnie wywodził się on ze szkoły flamandzkiej lub niderlandzkiej. Sam obraz był wzorowany na ikonie bizantyjskiej, stanowił część większego dzieła, a cechą, która wyróżnia go na tle innych wizerun-

2 Por. A. Witkowska OSU, J. Nastalska-Wiśnicka, Ku ozdobie i obronie Rzeczypospolitej. Maryjne miejsca święte $w$ drukach staropolskich, Lublin 2013, s. 45, 487, 508. Autorki dwukrotnie pisały o Janie Kazimierzu Steczkiewiczu, a raz o Janie Kazimierzu Steczewiczu jako autorze dzieła. Pierwszy, dodajmy, mylny zapis należy uznać za błąd w druku. Ten pogląd jest tym bardziej uzasadniony, że dotąd nikt nie kwestionował tej drugiej formy nazwiska autora księgi (J.K. Steczewicz), bo też nie ma ku temu żadnych podstaw.

3 Przypadki trudnych porodów oraz komplikacji zdrowotnych położnic stanowią przedmiot osobnej refleksji.

4 Sanktuarium rokitniańskie. Dzieje i konteksty, red. G. Chojnacki, A. Draguła, Zielona Góra 2009. Literaturę przedmiotu (w tym dewocyjną) odnoszącą się do Rokitna podały: A. Witkowska OSU, J. Nastalska-Wiśnicka, Ku ozdobie, s. 486 n. 
ków, jest odsłonięte ucho Maryi, stąd pełna nazwa: obraz Matki Bożej Rokitniańskiej Pani Cierpliwie Słuchającej5.

Inskrypcja łacińska umieszczona na obrazie pokazuje, że jednym z pierwszych jego posiadaczy był archidiakon kruszwicki Maciej Dąbrowski, który pod koniec XVI lub na początku XVII w. otrzymał go od Jana Sawickiego. Dalsze losy tego maryjnego wizerunku były bardzo burzliwe. Najpierw znalazł się w rękach Opalińskich i wtedy też miało dojść do pierwszej nadprzyrodzonej interwencji za pośrednictwem Matki Bożej (początek drugiej połowy siedemnastego wieku). W latach pięćdziesiątych XVII w. obraz wraz z Janem Piotrem Opalińskim trafił na teatr działań wojennych przeciwko Szwedom. Dekadę później syn Jana Kazimierz Jan, opat bledzewski, przejął ten wizerunek. Najpierw umieścił go we własnym pokoju, a następnie w bocznym ołtarzu kościoła klasztornego. Dodatkowo doświadczenie przez opata łaski przed wspomnianym obrazem wpłynęło na rozsławienie imienia Maryi i legło u podstaw narodzin ruchu pielgrzymkowego do Bledzewa. Jak obraz trafił do Rokitna? Otóż w 1669 r. K.J. Opaliński przybył do parafii w Rokitnie. Jakiś czas później poprosił o przesłanie obrazu, który powiesił w głównym ołtarzu kościoła. Ponieważ obraz przyciągał wiernych, Opaliński pod wpływem namów cystersów z Paradyża i J.K. Steczewicza, dziekana zbąszyńskiego, postanowił nie odsyłać wizerunku do Bledzewa $^{6}$.

Łaski doznane za pośrednictwem Matki Bożej, napływ pielgrzymów oraz bezpośrednie zaangażowanie K.J. Opalińskiego legły u podstaw powołania komisji. 11 II 1670 r. komisja zebrała się po raz pierwszy i zapisano wtedy siedemnaście świadectw. 3 III 1670 r. doszło do drugiej sesji komisji i podczas przesłuchań zgromadzono aż siedemdziesiąt sześć świadectw ${ }^{7}$. Efektem prac był dekret, na mocy którego zatwierdzano kult obrazu. Dodajmy też, że jednym z członków komisji był J.K. Steczewicz, autor opublikowanego zbioru zeznań. W 1672 r. to dziełko ukazało się po raz pierwszy pod tytułem: Skarb Nieprzebrany Dobrodzieystw Boskich. Obraz

5 B. Grabowska, Ikonografia przedstawienia Matki Bożej Rokitniańskiej, [w:] Sanktuarium rokitniańskie. Dzieje i konteksty, red. G. Chojnacki, A. Draguła, Zielona Góra 2009, s. 107-112, tu, s. 107-110.

6 Rok później obraz trafił na życzenie króla Michała Korybuta Wiśniowieckiego do Warszawy, skąd pod koniec 1671 r. powrócił do Rokitna. Tym wydarzeniom towarzyszyła przebudowa świątyni w samym Rokitnie, którą nadzorował K.J. Opaliński. Więcej o tych zdarzeniach i dalszych losach obrazu oraz kościoła: D. Śmierzchalski-Wachocz, Matka Boża Obozowa. Geneza i rozwój kultu obrazu Matki Bożej Rokitniańskiej do 1945 roku, [w: Sanktuarium rokitniańskie. Dzieje i konteksty, red. G. Chojnacki, A. Draguła, Zielona Góra 2009, s. 9-26, tu, s. 9-22.

7 O komisjach: tamże, s. 9-26, tu, s. 18. 
Cudowny Naświętszey Panny Mariey w Opactwie Bledzewskim Rokitnickiey. W 2014 r. wydano je po raz drugi ${ }^{8}$. W skład Skarbu Nieprzebranego weszły nie tylko zeznania złożone przed komisją, ale też świadectwa, których wysłuchał sam J.K. Steczewicz po zatwierdzeniu jego dziełka do druku'. Wszystkie zeznania zamieszczone w Skarbie Nieprzebranym dotyczyły zdarzeń mirakularnych z lat sześćdziesiątych i początku lat siedemdziesiątych XVII w.

W księdze opisano dziewięćdziesiąt osiem przypadków, z których dwanaście dotyczyło chorych dzieci, co daje $11,76 \%$ w stosunku do ogółu ${ }^{10}$. Już w tej chwili ujawnię, że jeśli dodamy do tych dwunastu przypadków nieszczęśliwe zdarzenia z udziałem nieletnich (trzy świadectwa), to powyższy odsetek zwiększy się do $14,7 \%^{11}$. Z kolei same wypadki losowe to zaledwie 2,94\%. Reasumując: prawie 1/6 zdarzeń mirakularnych opisanych w Skarbie Nieprzebranym dotyczyła małoletnich. Na marginesie uzupełnię, że liczba dziewięćdziesiąt osiem nie koresponduje z ogólną liczbą świadectw (sto dwa), ponieważ np. podczas spisywania okoliczności cudownego ugaszenia pożaru kilku świadków złożyło zeznanie ${ }^{12}$.

8 Niestety wydanie z 2014 r. ([J.K. Steczewicz], „Skarb Nieprzebrany Dobrodziejstw Boskich” Ks. Jana Kazimierza Steczewicza. Transkrypcja i komentarze, red. A. Sapieha, oprac. E. Skorupska-Raczyńska, tłum. J. Roman, Gorzów Wielkopolski 2014) posiada błędy np. „włodarka” została „przetłumaczona” jako „władczyni”, „panująca” (s. 95, przyp. 169). Poza tym nazwy miejscowości są niepoprawnie odczytane. Np. J.K. Steczewicz pisał o wsi Lubiekowo, którą powinniśmy identyfikować ze wsią Lubikowo. Dodajmy, że położoną w województwie lubuskim, w powieście międzyrzeckim. Za to w wydaniu jest mowa o wsi Lubiechowo (s. 86). Nieco inaczej rzecz się ma z wsią Szarcz (województwo lubuskie, powiat międzyrzecki). W jednym przypadku J.K. Steczewicz zapisał nazwę tej wsi jako Szarcza. W edycji uwzględniono ten ostatni zapis, ale zabrakło niestety komentarza, że takiej miejscowości nie ma. Za to właśnie istnieje wieś Szarcz (s. 104). Redaktorzy wydania ze zbyt wielką swobodą podeszli do: 1 . wyrazów, które należy interpretować jako definiujące zakres obowiązków czy oznaczające profesje, albo 2. nazw, które w formie żeńskiej umieszczono przy imieniu żony, a które pochodziły do nazwy profesji małżonka. Jako przykłady niech posłużą: „włodarka” (s. 95) i „Masztalerzowa” (s. 86). Ta ostatnia - nie wiedzieć, dlaczego - zapisana (w przeciwieństwie np. do „włodarki”) jako nazwisko. W związku ze wszystkimi powyższymi uwagami nie korzystam z tej edycji. Podkreślmy, że poza uwspółcześnionym zapisem wyrazów nie wnosi ona nic wartościowego.

9 J.K. Steczewicz, Skarb Nieprzebrany Dobrodziejstw Boskich. Obraz Cudowny Naświętszey Panny Mariey w Opactwie Bledzewskim Rokitnickiey, Poznań 1672, s. 261-267. Na temat innych dziełek związanych z Rokitnem: A. Witkowska OSU, J. Nastalska-Wiśnicka, Ku ozdobie, s. 487.

10 J.K. Steczewicz, Skarb Nieprzebrany, s. 146-149, 151, 153-155, 168-169, 188-189, 191$-192,196-197$.

11 Tamże, s. 200-201, 223, 225-229.

12 Tamże, s. 242-246. 
Co interesujące, J.K. Steczewicz wyłącznie w jednym przypadku odnotował wiek dziecka. Chodziło o dwuipółletnią Katarzynę, córkę Anny z Lubikowa. W księdze podano, że dziewczynka ciężko chorowała, to znaczy przez trzy tygodnie męczyły ją „boleści śmiertelne”, niewiele jadła i równie niewiele piła, a ponadto przez dwa tygodnie nie mówiła ${ }^{13}$. Z jednej strony ten niedostatek precyzyjnych danych co do wieku dzieci nie dziwi, jeśli weźmiemy pod uwagę nadrzędny cel ksiąg cudów i łask. Przecież miały one służyć przede wszystkim jako zbiór świadectw cudotwórczego charakteru obrazu lub dowodzić świętości osób ${ }^{14}$. W związku z tym istotne było zanotowanie samego cudownego zdarzenia, a zasób precyzyjnych danych dotyczących wotantów (poza np. imieniem i ewentualnie nazwiskiem) nie był warunkiem koniecznym. Z drugiej strony, jeśli weźmiemy pod uwagę dane dotyczące dzieci, które pochodzą z innych ksiąg cudów i łask, to przekonamy się, że taka lakoniczność nie cechowała wszystkich autorów. Np. Stanisław Józef Kłossowski, autor Cudów y task za przyczyna (...) Józefa świętego (...) w Kollegiacie Kaliskiey, podał wiek dwudziestu ośmiu nieletnich na blisko pięćdziesięciu czterech, czyli okazał się precyzyjny w prawie połowie dziecięcych przypadków ${ }^{15}$.

Czy lakoniczność J.K. Steczewicza i dla odmiany większą koncentrację na wieku dzieci u S.J. Kłossowskiego powinniśmy tłumaczyć metryką zdarzeń mirakularnych i tym samym ksiąg? Wszak mirakula ogłoszone przez tego drugiego autora były młodsze o około stulecie od cudów zebranych przez J.K. Steczewicza (lata 1673-1780 , przy czym zasadniczy zrąb świadectw pochodził z lat $1751-1780)^{16}$. Nie sądzę, aby pominięcie kwestii wieku stanowiło konsekwencję wspomnianej metryki. Jeśli przyjrzymy się analogicznym danym pochodzącym ze źródeł średniowiecznych (cuda Stanisława, Jadwigi, Jacka, Kingi, Salomei, biskupów Prandoty i Wernera oraz poznańska księga cudów kościoła Bożego Ciała), to przekonamy się, że na sześć-

13 J.K. Steczewicz, Skarb Nieprzebrany, s. 146; zapis cytatów został uwspółcześniony.

14 Por. J. Duffin, Medical Miracles. Doctors, Saints and Healing in the Modern World, Oxford 2009, s. $15 \mathrm{n}$.

15 Przypadki dzieci wraz z danymi na temat wieku: S.J. Kłossowski, Cuda y łaski za przyczyna y wzywaniem mniemanego oyca Jezusowego Józefa świętego, przy obrazie tegoż świętego Patryarchy $w$ Kollegiacie Kaliskiey (...) mitościwie uczynione, z procesu dwóch komissyi y zaprzysiężeń w konsystorzu kaliskim (...), Kalisz 1780, s. 13-16, 18-20, 23-25, 26-30, 32-34, 36-39, 65, 82, 130-132, 185-186, 191-192, 215, 226-227, 388-389; przypadki dzieci bez podanego wieku: tamże, s. $23-24,25,35-36,39,40,41,74,79,92,123,137,176-177,199,213,227-228,239-240$, 241, 245-246, 248, 279, 280.

16 E. Andrzejewska, Ks. Stanisław Józef Kłossowski (1726-1798), kustosz Sanktuarium św. Józefa $w$ Kaliszu, Kalisz 2010, s. 43. 
dziesiąt sześć dziecięcych przypadków jedynie w dwudziestu sześciu nie podano, ile dziecko liczyło wiosen ${ }^{17}$. Zatem autorzy tych tekstów byli bardziej dokładni niż „młodszy” J.K. Steczewicz. Dodajmy, że jedynie w księdze cudów Jadwigi śląskiej $\mathrm{w}$ dziesięciu przypadkach na piętnaście pominięto dane związane $\mathrm{z}$ wiekiem. Z kolei w pozostałych wiek podano w połowie świadectw lub we wszystkich (cuda Salomei, Prandoty i Wernera) $)^{18}$.

W przypadku nieszczęśliwych zdarzeń z udziałem małoletnich (trzy świadectwa) raz podano wiek dziecka. Ten jednostkowy przypadek to opis zdarzenia mirakularnego z udziałem dziewięcioletniego syna Mateusza Ciemnego, zagrodnika ze wsi Perzyny (niedaleko Zbąszynia). Sam Mateusz trudniący się okazjonalnie połowem ryb, prosił dzieci, aby w wietrzne dni pilnowały, by fala nie zniosła go zbyt daleko. Wieczorem jego syn widząc, że wiatr się zerwał, przerwał na chwilę pasanie wołów, udał się nad jezioro i postanowił szukać ojca. W tym celu chłopiec wsiadł do dziurawego czółna. Nie zamierzał oddalać się od brzegu, a jedynie sprawdzić, gdzie jest ojciec. Niestety i jego czółno zniósł wiatr. Chłopiec dryfując, dotarł w nocy do innej wsi, w której na drugi dzień odnaleźli go poszukujący go od wieczora rodzice ${ }^{19}$. Na marginesie dodam, że w dwóch kolejnych świadectwach, w których J.K. Steczewicz nie sprecyzował wieku dzieci, po prostu zasygnalizował okres dziecięcy pisząc o „chłopcu” czy o „dziecięciu małym” (zresztą analogicznie czynił w opisach uzdrowień dzieci ${ }^{20}$. W takich wypadkach możemy ostrożnie założyć, że prawdopodobnie mieliśmy do czynienia z dzieckiem kilkuletnim, skoro podano, że było małe.

We wszystkich świadectwach dotyczących uzdrowień i ratunku dzieci od następstw nieszczęśliwych zdarzeń była mowa o przywróceniu zdrowia lub udzieleniu pomocy, nie zaś o wskrzeszeniu pozornie umarłego ${ }^{21}$. Jaki wniosek stąd płynie? Otóż rodzice nie zwlekali i zanim dziecko doszło do kresu życia, szukali pomocy u Opatrzności, która za pośrednictwem Matki Bożej Rokitniańskiej miała nieść ratunek. Powyższa uwaga o braku wskrzeszeń dzieci nie oznaczała, że stan np. chorych nie był ciężki. Tę kwestię omówię bardziej szczegółowo w dalszej części, teraz jedy-

\footnotetext{
17 Na temat wieku chorych dzieci w średniowiecznych mirakulach: M. Delimata, Choroby dzieci na podstawie średniowiecznych polskich katalogów cudów świętych, Nasza Przeszłość 101 (2004), s. 437-449.

18 Tamże, s. 446.

19 J.K. Steczewicz, Skarb Nieprzebrany, s. 225-229.

20 Tamże, s. 200, 223.

21 Tamże, s. 146-149, 151, 153-155, 168-169, 188-189, 191-192, 196-197, 200-201, 223, 225-229.
} 
nie zasygnalizuję, że w jednym przypadku dziecko uznano za konające, a w czterech dzieci były dotknięte jakąś śmiertelną chorobą ${ }^{22}$.

J.K. Steczewicz okazał się równie powściągliwy, jeśli mówimy o sygnalizowaniu płci ocalonych dzieci. Jedynie w pięciu przypadkach na piętnaście podał płeć i tak w dwóch świadectwach doniesiono o ocaleniu dziewczynek, a w trzech o uratowaniu chłopców ${ }^{23}$. Jeśli weźmiemy pod uwagę te pięć przypadków, zobaczymy, że nie ma mowy o dysproporcji między wskazanymi dwiema grupami. W związku z tym nie możemy przyjąć, że rodzice bardziej zabiegali o pomoc dla synów, a w przypadku córek wykazali mniej troski ${ }^{24}$.

Symptomatyczny wydaje się udział chłopców w nieszczęśliwych zdarzeniach. Wprawdzie dysponujemy jedynie trzema zapiskami, ale w dwóch wskazano na płeć męską. Za to w trzecim nie podano, czy mieliśmy do czynienia z chłopcem czy dziewczynką ${ }^{25}$. Dodam również, że w tych dwóch przypadkach mieliśmy do czynienia z zaangażowaniem dzieci po części w „męskie” prace gospodarskie, które wymagały siły fizycznej. Te dwa wspomniane przypadki dotyczyły: 1. omawianej „przygody” syna Mateusza Ciemnego, który dryfował w dziurawym czółnie; 2. anonimowego chłopca, który podczas karmienia koni, postawił konew z wodą zbyt blisko zwierzęcia. Wskutek tego koń się spłoszył i najpierw strącił chłopca ze żłobu, a następnie go stratowat ${ }^{26}$.

Czy niedostatek danych dotyczących płci możemy uznać za znamienny i, co za tym idzie, za ilustrujący ogólny stosunek dorosłych do dzieci? Mogłoby się wydawać, że pominięcie problemu płci (a przedtem kwestii wieku) oznacza, że dzieci nie traktowano z należytą uwagą; nie koncentrowano się na nich. Idąc tropem Philippe’a Arièsa, marginalizowano je, wręcz nie zauważano ich ${ }^{27}$. Sądzę, że w przypadku ksiąg cudów i lask odpowiedź nie powinna być twierdząca. Biorąc pod uwagę wspominany przy okazji omawiania wieku dzieci jeden z celów tych tekstów, nie dziwi brak koncentracji J.K. Steczewicza na zagadnieniach, które były dla niego marginal-

\footnotetext{
22 Tamże, s. 146-149, 154-155.

23 Dziewczynki: tamże, s. 146, 154-155; chłopcy: tamże, s. 147, 200-201, 225-229.

24 O szczególnej pozycji synów m.in.: B. Popiołek, Kobiecy świat w czasach Augusta II. Studia nad mentalnością kobiet z kręgów szlacheckich, Kraków 2003, s. 32 n.

25 J.K. Steczewicz, Skarb Nieprzebrany, s. 223.

26 Tamże, s. 200-201, 225-229.

27 P. Ariès, Historia dzieciństwa. Dziecko i rodzina w dawnych czasach, tłum. M. Ochab, Gdańsk 1995, passim.
} 
ne. Przecież J.K. Steczewiczowi zależało przede wszystkim na zebraniu dowodów na cudotwórczy charakter obrazu Matki Bożej Rokitniańskiej. W centrum jego zainteresowań był cud, doznana łaska i wszystko to, co z nimi związane na płaszczyźnie religijnej i duchowej. Pozostałe kwestie jak np. dane osobowe pielgrzymów były drugorzędne.

W czterech świadectwach doniesiono, że dzieci zapadły na jakąś ciężką, a nawet śmiertelną chorobę. Poza tym we wszystkich przypadkach zabrakło opisu symptomów specyficznych, bo przecież za takie nie możemy uznać „boleści śmiertelnych”, które odczuwała Katarzyna z Lubikowa lub braku laknienia ${ }^{28}$. Dodatkowo odnotowany w zeznaniu dotyczącym Katarzyny brak komunikacji z otoczeniem też nie był symptomem specyficznym, a jedynie mógł stanowić konsekwencję znacznie podwyższonej temperatury lub wspomnianych „boleści śmiertelnych”. Dodajmy, że w omawianym świadectwie nie odnotowano także, w której części ciała dziewczynka odczuwała owe bóle. Nie inaczej poinformowano o dolegliwościach anonimowej córeczki pewnej kobiety. Matka zeznała, że dziewczynka ciężko chorując doszła do kresu życia, co stwierdzono w następujący sposób: dziecko „mowę było straciło i oziębło"29. Powtórzę, że brak komunikacji z otoczeniem nie jest symptomem, a obniżenie temperatury ciała (pytanie, na ile było to subiektywne odczucie matki, a na ile rzeczywiście do takiego stanu doszło) następuje w przebiegu wielu chorób i pod wpływem rozmaitych czynników zewnętrznych. W związku z tym w obu powyższych przypadkach jakakolwiek diagnoza jest wykluczona.

Jeszcze mniej wartościowe poznawczo i niemożliwe do rozpoznania były dwa przypadki, w których jedynie podano, że: 1. Jakub Lewicki widział: „dziecię swoje w ciężkiej a prawie śmiertelnej chorobie zostające”; 2. dziecko Jana Chojnackiego było „śmiertelnie chorujące”30 Za to J.K. Steczewicz doniósł o przypadkach epilepsji wśród dzieci. Mieliśmy do czynienia z czterema takimi świadectwami ${ }^{31}$. Warto wyjaśnić, dlaczego akurat „kaduk” był tak rozpoznawalny, że bez wahania go diagnozowano ${ }^{32}$. Otóż „kaduk”, „wielka choroba” budził spore emocje, które wynikały po pierwsze: ze spektakularnego charakteru napadów, po drugie: z poglądów na przyczyny epilepsji, które formułowano od antyku, po trzecie: z faktu, że jeszcze

\footnotetext{
28 J.K. Steczewicz, Skarb Nieprzebrany, s. 146.

29 Tamże, s. 154.

30 Tamże, s. 148-149.

31 Tamże, s. 188-189, 191-192, 196-197.

32 Tamże, s. 188-198.
} 
w XVIII w. mało wiedziano na temat jej etiologii. Tym samym epilepsja ujawniała bezradność medyków i medycyny ${ }^{33}$.

W starożytności sądzono, że „wielka choroba” ma boskie podłoże. Z kolei w średniowieczu epilepsję kojarzono z opętaniem, a niekiedy postrzegano ją jako dopust Boży. Wierzono, że „wielką chorobę” zesłała Opatrzność, aby ukarać grzeszników za wyjątkowo ciężkie występki ${ }^{34}$. Od razu wyjaśnijmy, że we wspomnianych czterech przypadkach epilepsji, które J.K. Steczewicz opisał, brakuje jakichkolwiek uwag nawiązujących do negatywnego postrzegania napadów epileptycznych. Zwłaszcza nie ma mowy o korelacji między „kadukiem” a karą za ciężkie grzechy. Skąd to wiemy? Zdaniem Elżbiety Nowosielskiej o takim związku świadczyłyby szczegółowe opisy nie tyle samej choroby, ile kondycji moralnej, a także czynów osób chorych, a takowych nie spotykamy w interesujących nas świadectwach. Poza tym z obserwacji tej badaczki wynikało, że nie dostrzegano związku między epilepsją dzieci a grzechem np. rodziców tym bardziej, jeśli w zapiskach nie podano informacji na temat moralności tych ostatnich ${ }^{35}$. Podkreślmy, że J.K. Steczewicz również nie wspominał o jakiejkolwiek winie rodziców ${ }^{36}$.

Pozostałe cztery zapiski, które odnosiły się do chorych dzieci, także nie pozwalają na precyzyjną diagnozę. W jednym przypadku podano, że wnuczek Władysława Kłodzińskiego konał, w następnym zanotowano, że dziecko pani Korzeniewskiej było „ledwie żyjące i całe opłakane”, a z kolei dziecko Anny Wieczorkowej okazało

33 J. Jagla, Chory psychicznie - epileptyk - histeryk. Obraz człowieka opętanego w sztuce średniowiecznej, [w:] Wokót choroby, medycyny i praktyk leczniczych. Teorie - konteksty - interpretacje, red. K. Łeńska-Bąk, M. Sztandara, Opole 2009, s. 167-177, tu, s. 168-169; B. Klukowska, Higiena dziecka i choroby wieku dziecięcego na ziemiach polskich w świetle osiemnastowiecznych poradników medycznych, [w:] Wśród córek Eskulapa. Szkice z dziejów medycyny i higieny w Rzeczypospolitej XVI-XVIII wieku, red. A. Karpiński, Warszawa 2009, s. 313-351, tu, s. 347; K. Koper, Sposoby niesienia pomocy $w$ chorobach „prędkiego ratunku potrzebujących” w świetle XVIII $i$ XIX-wiecznych poradników medycznych, [w:] Wśród córek Eskulapa. Szkice z dziejów medycyny i higieny w Rzeczypospolitej XVI-XVIII wieku, red. A. Karpiński, cz. 2, Warszawa 2015, s. 259-314, tu, s. 298-299. 34 J. Jagla, Boska Medycyna i Niebiescy Uzdrowiciele wobec kalectwa i chorób człowieka. Ikonografia "Patronów od chorób" i „Świętych Mitujących Żebraków” w sztuce polskiej XIV-XVII w., Warszawa 2004, s. 139 n.; E. Nowosielska, Epilepsja w Rzeczypospolitej w XVII-XVIII w., [w:] Wśród córek Eskulapa. Szkice z dziejów medycyny i higieny w Rzeczypospolitej XVI-XVIII wieku, red. A. Karpiński, cz. 2, Warszawa 2015, s. 219-257, tu, s. 222-251, 254; por. W. Piotrowski, Polska medycyna oświeceniowa, Jawor 1997, s. 49; J. Węglorz, Zdrowie, choroba i lecznictwo w społeczeństwie Rzeczypospolitej XVI-XVIII wieku, Torun 2015, s. 119 n.

35 J. Jagla, Boska Medycyna, s. 153; E. Nowosielska, Epilepsja, s. 219-257, tu, s. 254-256.

36

J.K. Steczewicz, Skarb Nieprzebrany, s. 188-189, 191-192, 196-197. 
się „ułomne na wszystkich członkach od urodzenia”. W związku z tym ani nie podnosiło się samodzielnie, ani nie chodziło ${ }^{37}$. W tym ostatnim przypadku mieliśmy być może do czynienia z nieprawidłowościami w budowie kręgosłupa lub, co bardziej prawdopodobne, $\mathrm{z}$ jakimś porażeniem ${ }^{38}$. Niestety, precyzyjna diagnoza ponownie nie jest możliwa z powodu braku bardziej szczegółowych danych. Tym bardziej nieuprawnione wydaje się wskazanie na chorobę Heinego-Medina czy mózgowe porażenie dziecięce (chorobę Little’a), choć w tym wypadku cisną się one pod pióro jako najbardziej rozpoznawalne ${ }^{39}$. Podobnie nie wiemy, z jakim schorzeniem mieliśmy do czynienia, kiedy mówimy o dziecku Katarzyny ze wsi Szarcz (klucz pszczewski),

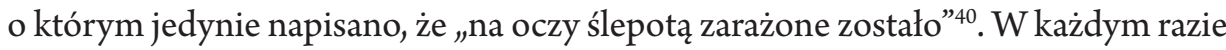
przypadek tego dziecka wpisywał się w ogólną sytuację panującą w XVII w. W tym stuleciu, jak i w następnym, zaburzenia widzenia były często spotykane jako konsekwencja niedożywienia oraz pokłosie innych chorób czy to neurologicznych czy to bardzo powszechnych schorzeń narządu wzroku ${ }^{41}$.

O dwóch przypadkach nieszczęśliwych zdarzeń z udziałem dzieci oraz zaangażowaniu w nie chłopców (nie dziewczynek) wspominałam. W jednym, dotąd nie omówionym świadectwie opisano wypadek, który przydarzył się dziecku Jana Chojnackiego z Międzyrzecza. J.K. Steczewicz zanotował, że dziecko wpadło do sadzawki, trzykrotnie się zanurzyło i prawie utonęło. Po ofiarowaniu dziecka przez matkę Matce Bożej Rokitniańskiej bezpiecznie dopłynęło do rodzicielki ${ }^{42}$. Ten przypadek, choć mało wartościowy z uwagi na brak informacji o okolicznościach sprawy (dlaczego dziecko wpadło do wody, dane na temat jego wieku i płci itd.), okazał się interesujący z powodu nawiązania do biblijnej symboliki. Niedawno sformułowalam pogląd na temat analogicznych odniesień u księdza Surmatowskiego, który na

\footnotetext{
37 Tamże, s. 147, 151, 153-154.
}

38 Dla porównania podam, że dla okresu średniowiecza stwierdzono występowanie wad rozwojowych kręgosłupa, które rzutowały na brak ogólnej sprawności: J. Tyszkiewicz, Człowiek w środowisku geograficznym Polski średniowiecznej. Związki i uwarunkowania przyrodniczo-kulturowe, Warszawa 1981, s. 99 n.

39 Choroba Heinego-Medina występowała często w wiekach wcześniejszych: J. Tyszkiewicz, Człowiek, s. 100 n.; tenże, Ludzie i przyroda w Polsce średniowiecznej, Warszawa 1983, s. 148.

40 J.K. Steczewicz, Skarb Nieprzebrany, s. 168-169.

41 W. Piotrowski, Medycyna polska epoki kontrreformacji (1600-1764), Jawor 1996, s. 51 n., 85 n.; tenże, Polska medycyna, s. 46 n. Również w okresach wcześniejszych choroby oczu były nagminne: J. Tyszkiewicz, Człowiek, s. 102; tenże, Ludzie, s. 149.

42 J.K. Steczewicz, Skarb Nieprzebrany, s. 223. 
kartach Prospektu Wesołego, Miłosiernych Oczu, Przenayświętszey Maryi, (...) z Gory S. Gostynskiey wielokrotnie operował cyfrą trzy i siedem ${ }^{43}$. Podobnie u J.K. Steczewicza spotykamy nawiązania do tej pierwszej cyfry i to nie tylko w zapiskach dotyczących dzieci. Np. wspomniana Anna z Lubikowa odmówiła trzykrotnie „Pozdrowienie Anielskie”; jej córkę przez trzy tygodnie męczyły „boleści śmiertelne”; pewien człowiek z Bledzewa przez trzy miesiące „w szaleństwie, albo bez rozumu chodził”; kucharz Franciszek przez trzy dni zmagał się z gorączką, a Michał Pada trzeciego dnia wyzdrowiat ${ }^{44}$. Z jednej strony cyfra trzy to komplementarność, doskonałość (Trójca Święta), z drugiej zaś gdy mówimy o świętym Piotrze, który trzykrotnie wyparł się Jezusa ( J 18,15-27), to mamy na myśli zapowiedź czynu i niejako gwarancję jego wypełnienia [poza tym np. Piotr został trzykrotnie powołany do opieki nad Owczarnią Pańską (J 21, 17) $]^{45}$. W związku z powyższym jak powinniśmy interpretować cyfrę trzy u J.K. Steczewicza? Otóż jest to zwiastun łaski i jednocześnie zapewnienie o jej zesłaniu. Za to wspomniany Michał Pada wyzdrowiał trzeciego dnia, co z kolei przywodzi na myśl samego Chrystusa, który trzeciego dnia zmartwychwstał (Mk 16, 1-7).

Emocje związane z dramatyczną sytuacją chorych lub zagrożonych dzieci wyrażały otwarcie głównie matki. W księdze odnajdujemy dwa takie przypadki. Wspomniana powyżej małżonka Jana Chojnackiego „utrapiona” faktem, że jej dziecko tonęło, krzyknęła: „Najśw. Panno Rokitnicka ratuj to dziecię, żeby nie utonęło”" Na równi przygnębiona i zasmucona była Jadwiga, matka dziecka cierpiącego na epilepsję $^{47}$. Poza tym z powyższego zestawienia wynika, że brakuje odniesień do ojcowskich reakcji na wieść o nieszczęściach, które spotkały dzieci. Lęk ojca wzmiankowano tylko wtedy, gdy towarzyszył on obawie żony ${ }^{48}$.

Nie powinniśmy interpretować jako niedostatku troski rodziców o dzieci wspomnianych powyżej trzech zapisek. Po prostu J.K. Steczewicz nie wzmiankował stanu emocjonalnego matek i ojców, za to opisał ich zaangażowanie w ratowanie potom-

\footnotetext{
43 Np. M. Delimata-Proch, Choroby w świetle „Prospektu Wesołego, Miłosiernych Oczu, Przenayświętszey Maryi, (...) z Gory S. Gostynskiey" (XVI-XVIII w.), Kwartalnik Historii Kultury Materialnej 66 (2018), nr 3, s. 281.

44 J.K. Steczewicz, Skarb Nieprzebrany, s. 146, 206, 159-160, 174.

45 V. Hopper, Medieval Number Symbolism. Its Sources, Meaning, and Influence on Thought and Expression, New York 2000, s. 107.

46 J.K. Steczewicz, Skarb Nieprzebrany, s. 223.

47 Tamże, s. 191-192.

48 Tamże, s. 225-229.
} 
ków, a także w gesty wotywne, które z jednej strony prowokowały cud, z drugiej natomiast stanowiły wyraz dziękczynienia za łaskę. Problemem rodziców poszukujących pomocy medycznej i samą pomocą zajmę się za moment. Teraz odnotujmy, że w większości przypadków to rodzice byli wotantami i poza czterema przypadkami mieliśmy do czynienia z zupełnym zastępstwem, czyli sytuacją, w której w imieniu chorego lub poszkodowanego występował ktoś inny. Wspomniane cztery wyjątki to: 1. „przygoda” syna Mateusza Ciemnego. Jego rodzice prosili Opatrzność o ratunek, zaś chłopiec przez cały czas odmawiał pacierz; 2.-3. uzdrowienie dzieci: Anny Wieczorkowej i Jana Ptaka z Rokitna. W obu wypadkach chore dzieci zaniesiono przed obraz; 4. uleczenie z epilepsji dziecka Barbary z Bledzewa. Kobieta w ramach dziękczynienia przyprowadziła dziecko do sanktuarium ${ }^{49}$.

W trzynastu przypadkach (na piętnaście świadectw) opisano udział rodziców w praktykach i to same matki ofiarowały dzieci najczęściej.J.K. Steczewicz wspominał o siedmiu takich przypadkach ${ }^{50}$. Na drugim miejscu zanotował zaangażowanie ojców (trzy razy) ${ }^{51}$. W omawianej księdze wymieniono trzykrotnie oboje rodziców, a także raz dziadków i raz samą babcię ${ }^{52}$. $Z$ jednego zeznania wynikało, że wotantem był także Mateusz Popiński, pleban z Bledzewa. Chodziło o przypadek chłopca, który został stratowany przez spłoszonego konia ${ }^{53}$.

$\mathrm{Z}$ drugiej strony pozostaje pytanie, na które nie jestem w stanie udzielić odpowiedzi, to znaczy: na ile matki chorych dzieci działały pod wpływem uczuć rodzicielskich, a na ile po prostu obawiały się życia z niepełnosprawnym, czyli dożywotnio niesamodzielnym dzieckiem? Przecież nie możemy wykluczyć tej ostatniej ewentualności. Ta wątpliwość dotyczy np. zapisek, w których J.K. Steczewicz wymienił: 1. dziecko Anny Wieczorkowej, o którym wspominałam, a które było „ułomne na wszystkich członkach od urodzenia”; 2. dziecko Katarzyny ze wsi Szarcz, które straciło wzrok $^{54}$. Te zastrzeżenia co do istnienia więzi emocjonalnych korespondowałyby z wnioskiem, który Aneta Bołdyrew sformułowała dekadę temu. Jej zdaniem do początków XIX w. stosunek matek do dzieci był obojętny. Dopiero od tego okresu

\footnotetext{
49 Tamże, s. 151, 196-197, 192, 225-229.

50 Tamże, s. 146, 151, 154-155, 168-169, 188-189, 191-192, 223.

51 Tamże, s. 149, 196-197.

52 Tamże, s. 146, 147, 148, 153-154, 225-229; tu mieliśmy do czynienia z przypadkiem podwójnym, to znaczy dwuipółletnia Katarzyna została ofiarowana przez matkę i babcię, tamże, s. 146.

53 Tamże, s. 200-201.

54 Tamże, s. 151, 168-169.
} 
datujemy przemiany nie tylko w świecie emocji, ale także w funkcjonowaniu całej rodziny ${ }^{55}$. Niestety weryfikacja (lub akceptacja) opinii A. Bołdyrew w odniesieniu do ksiąg cudów i łask wymaga osobnych studiów ${ }^{56}$.

$\mathrm{Z}$ zaangażowaniem najbliższych było ściśle związane zagadnienie gestów wotywnych. Jeśli mówimy o gestach proszalnych, czyli tych, które miały sprowokować cud, to w Skarbie Nieprzebranym we wszystkich dziecięcych przypadkach opisano prośbę skierowaną do Boga za pośrednictwem Matki Bożej Rokitniańskiej ${ }^{57}$. Z kolei w ośmiu świadectwach wspomniano wyłącznie o tej formie gestu ${ }^{58}$.

J.K. Steczewicz wzmiankował modlitwy jako gesty proszalne. Obok konkretnych modlitw (o nich za moment) mieliśmy do czynienia z takimi, których nazw nie podano lub po prostu z modlitwami autorskimi. Podkreślmy, że szczególnie te ostatnie ściśle łączą się ze wspomnianymi w poprzednim akapicie prośbami, wszak samodzielnie formułowane modły są niczym innym jak błaganiem o pomoc czy wręcz okrzykiem błagalnym ${ }^{59}$. W dwóch przypadkach J.K. Steczewicz zacytował słowa rodziców. Dodam, że owi rodzice wygłosili je w dramatycznych okolicznościach zagrożenia życia dziecka wskutek losowych zdarzeń. W pierwszym omawianym przypadku chodziło o tonące dziecko. Matka widząc całą sytuację, krzyknęła: „Najśw. Panno Rokitnicka ratuj to dziecię, żeby nie utonęło"60. Z kolei w drugim rodzice poszukujący zaginionego na jeziorze syna, gdy dowiedzieli się, że w oddali widać dryfujące czółno, zawołali: „jeżeli to syn nasz, Najśw. Panno Rokitnicka ratuj że go" ${ }^{61}$.

\footnotetext{
55 A. Bołdyrew, Matka i dziecko, s. 230 n.

56 Rozważania na temat miłości macierzyńskiej w omawianym okresie stanowiły do lat przedmiot analiz. Nie czas ku temu, aby wymieniać wszystkich autorów zajmujących się tą problematyką. Warto jedynie wskazać publikacje, w których sformułowano nieco inne wnioski niż te, których autorką była A. Bołdyrew. Mam na myśli monografię Bożeny Popiołek z 2003 r. pt. Kobiecy świat, s. 168 n. oraz nowszą od niej publikację A. Jakuboszczak, Rodzina i rodzinność szlachcianek wielkopolskich w XVIII wieku. Perspektywa kobieca, Poznań 2016, s. 65.

57 J.K. Steczewicz, Skarb Nieprzebrany, s. 146-149, 151, 153-155, 168-169, 188-189, 191$-192,196-197,200-201,223,225-229$.

58 Tamże, s. 147-148, 153-154, 168-169, 188-189, 191-192, 197, 223.

59 Tamże, s. 147-149, 153-154, 168-169, 188-189, 191-192, 197, 223, 225-229; na temat modlitw autorskich i okrzyków błagalnych w innych księgach: P. Kowalski, Prośba do Pana Boga. Rzecz o gestach wotywnych, Wrocław 1994, s. 175.

60 J.K. Steczewicz, Skarb Nieprzebrany, s. 223.

61 Tamże, s. 225-229.
} 
Wśród modlitw zanotowano również takie, które przybierały formę obowiązującą w liturgii. W tej grupie opisano pojedyncze: pacierz, czyli zbiór kilku modlitw w tym „Modlitwa Pańska”, „Pozdrowienie Anielskie”, „Skład Apostolski”, „Dziesięć Przykazań” itd. i samo „Pozdrowienie Anielskie”. Wspomniany pacierz odmawiał wielokrotnie wzmiankowany syn Mateusza Ciemnego. Powtórzmy, że był to jeden spośród czterech przypadków, w których samo dziecko było wotantem ${ }^{62}$. Z kolei babcia dwuipółletniej Katarzyny z Lubikowa odmówiła aż trzykrotnie „Pozdrowienie Anielskie"63.

J.K. Steczewicz opisał cztery przypadki pielgrzymki rodziców przed obraz. $\mathrm{W}$ dwóch była mowa o zaniesieniu dzieci do świątyni i tym samym o rytach rewitalizacyjnych, a w dwóch pozostałych o samotnej wyprawie rodziców. W pierwszym świadectwie przedstawiono sytuację dziecka Anny Wieczorkowej, które, przypomnijmy, było „ułomne na wszystkich członkach od urodzenia”. Wspomniane przyniesienie dziecka przed obraz Matki Bożej Rokitniańskiej miało terapeutyczny wymiar. Gdy znalazło się ono w sferze sacrum, zostało uzdrowione (ryt rewitalizacyjny $)^{64}$. Podobny los spotkał dziecko Jana Ptaka z Rokitna. Kontakt z sacrum, czyli zaprowadzenie dziecka przed obraz, miał ozdrowieńczy skutek i odtąd dziecko nie doświadczało napadów epileptycznych ${ }^{65}$. Za to w dwóch zapiskach doniesiono, że mimo braku kontaktu z sacrum ciężko chorym dzieciom również zostało przywrócone zdrowie po tym, gdy sami rodzice udali się na pielgrzymkę ${ }^{66}$.

W Skarbie Nieprzebranym spotykamy sporadycznie inne gesty proszalne. Wotanci raz ślubowali pielgrzymkę, raz ofiarowali wotum, a poza tym raz odprawiono mszę świętą w intencji dziecka. Ślub pielgrzymki dziwi, ponieważ księgi cudów i łask stanowiły zbiór zeznań pielgrzymów, a poza tym cud należało ogłosić, zatem każdy wotant był niejako zobowiązany do udania się do sanktuarium ${ }^{67}$. Mimo to zdarzały się przypadki osobnego składania obietnicy peregrynacji. Tak było w przypadku dwuipółletniej Katarzyny, w imieniu której zobowiązanie złożyła babcia. Dodajmy, że kobieta nie tylko ślubowała pielgrzymkę, ale także wotum - chodziło o świecę

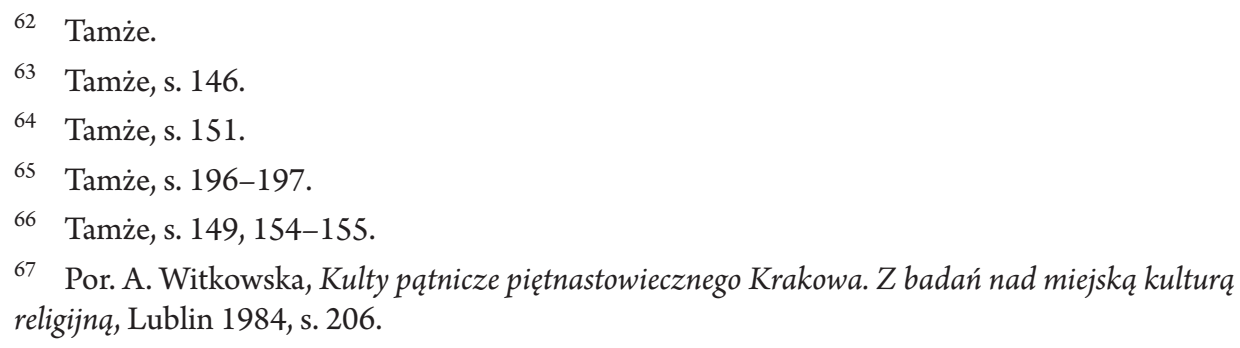


tak wysoką jak chore dziecko ${ }^{68}$. W tym ostatnim przypadku mieliśmy do czynienia z wotum zastępczym czy raczej symbolicznym, to znaczy, że przedmiot modlitwy (tu dziecko a de facto jego wzrost) był powielany i składany w ofierze (zasada pars pro toto $)^{69}$. Za to mszę w intencji chłopca stratowanego przez konia odprawil pleban, który jako jedyny zatroszczył się o poszkodowanego. W tym wypadku brakuje jakiejkolwiek wzmianki o rodzicach ${ }^{70}$.

Czy wspomniany powyżej ślub pielgrzymki został wypełniony? Zapewne tak było. W innym przypadku mielibyśmy do czynienia $\mathrm{z}$ „cudem-karą”, czyli przestrogą, aby nie lekceważyć podjętego zobowiązania. Wszak złożenie ślubów traktowano jako zawarcie umowy z Opatrznością, w ramach której gest był zapłatą ${ }^{71}$. Złamanie ślubu groziło nawrotem choroby, pojawieniem się rozmaitych trudności lub w skrajnym przypadku śmiercią ${ }^{72}$. Poza tym J.K. Steczewicz podał, że rodzina Katarzyny złożyła zeznanie, a nie mogło do tego dojść inaczej jak tylko po pielgrzymce.

Formułowanej prośbie czy modlitwie powinna towarzyszyć odpowiednia postawa wotantów. Co interesujące w przypadku dzieci, nie zaznaczono np. ufności rodziców i tylko raz mieliśmy do czynienia z zasygnalizowaniem jakiejś formy uniżenia. W zeznaniu dotyczącym pewnej anonimowej dziewczynki, która zapadła na ciężką chorobę, zapisano, że jej matka padła krzyżem przed obrazem Matki Bożej Rokitniańskiej ${ }^{73}$. Czy prostrację, bo o niej tu mowa, możemy uznać za gest proszalny? Sądzę, że tak. Wprawdzie sama prostracja oznacza maksymalne uniżenie przed

68 J.K. Steczewicz, Skarb Nieprzebrany, s. 146; woskowe świece jako dary były najbardziej popularne w średniowieczu. O genezie i dziejach tego wotum: J. Jagla, Gest wotywny. Ze starożytnych sanktuariów do chrześcijańskich świątyń i średniowiecznej ikonografii, [w:] Antyk, prawda i fałsz $w$ średniowieczu. Materiaty Seminariów Mediewistycznych im. Alicji Karłowskiej-Kamzowej, red. J. Kowalski, T. Ratajczak, Poznań 2011, s. 259-270, tu, s. 263-264.

69 Na temat tej praktyki: P. Kowalski, Prośba, s. 186.

70 J.K. Steczewicz, Skarb Nieprzebrany, s. 200-201.

71 R.C. Finucane, Miracles and Pilgrims. Popular Beliefs in Medieval England, London 1977, s. $93 \mathrm{n}$.

72 „Cud-kara” dotyczył także sytuacji, w której podważono moc postaci darzonej kultem lub nie okazano jej szacunku. „Cud-kara” był znany już w średniowieczu i przetrwał w niezmienionej formie, A. Witkowska, Kulty patnicze, s. 214-215; J. Kuuliala, Disability and Religious Practices in Late Medieval Prussia: Infirmity and the Miraculous in the Canonization Process of St. Dorothea of Montau (1404-1406), [w:] Lived Religion and the Long Reformation in Northern Europe c. 1300-1700, eds S. Katajala-Peltomaa, R.M. Toivo, Boston 2016, p. 64-71, tu, p. 64-71; por.: E. Wheatley, Stumbling Blokcs Before the Blind. Medieval Constructions of a Disability, Ann Arbor 2010, p. 179 n.

73 J.K. Steczewicz, Skarb Nieprzebrany, s. 154-155. 
Bogiem i towarzyszy często głębokiej modlitwie, ale jest także gestem, który ma nakłonić Opatrzność do interwencji.

Również zdziwienie budzi odnotowanie pielgrzymki jako gestu dziękczynnego. Powtórzmy, że z uwagi na charakter ksiąg wszyscy wotanci byli zobowiązani do peregrynacji i ogłoszenia łaski. Mimo to w Skarbie Nieprzebranym trzykrotne wspomniano o tej formie dziękczynienia ${ }^{74}$. Zresztą nie była to sytuacja wyjątkowa. Np. we wspominanych Cudach y laskach S.J. Kłossowskiego także wyszczególniono pielgrzymowanie do sanktuarium jako gest dziękczynny ${ }^{75}$. W odniesieniu do zarysowanej kontrowersji moglibyśmy zadać pytanie o jakiś wspólny mianownik zeznań opisanych w Skarbie Nieprzebranym, który tłumaczyłby odnotowanie pielgrzymki dziękczynnej? Otóż nic nie łączy tych relacji. W pierwszym przypadku chodziło o wzmiankowane dziecko Katarzyny ze wsi Szarcz, które „na oczy ślepotą zarażone zostało”, w drugim o epilepsję, natomiast w trzecim o wielokrotnie opisywaną „przygodę" syna Mateusza Ciemnego ${ }^{76}$.

W Skarbie Nieprzebranym raz doniesiono, że matka przybyła przed obraz wraz $\mathrm{z}$ uzdrowionym dzieckiem ${ }^{77}$. Zaangażowanie dziecka $\mathrm{w}$ ten gest dziękczynny miało dwojaki wymiar. Z jednej strony stawało się ono wotantem, o czym wspominałam, $\mathrm{z}$ drugiej natomiast zaprowadzenie dziecka narzucało mu rolę bezpośredniego świadka. Dziecko zaświadczało własną kondycją o doznanej łasce po pierwsze: formalnie, bo stan dziecka był „dowodem” w sprawie poświadczenia cudotwórczego charakteru obrazu. Po drugie, chodziło o przekonanie obecnych w sanktuarium wiernych o mocy Matki Bożej Rokitniańskiej i tym samym o rozsławienie jej imienia.

J.K. Steczewicz częściej pisał o wotum dziękczynnym niż proszalnym. Te prawdopodobne trzy (a pewne dwie) zapiski to świadectwa: 1. Władysława Kłodzińskiego, którego wnuczek konał; 2 . Anny Wieczorkowej, której dziecko dotknięte było paraliżem i 3. być może Mateusza Ciemnego ${ }^{78}$. W ostatnim przypadku wątpliwości wywołuje uwaga J.K. Steczewicza, zgodnie z którą Mateusz wraz z żoną ofiarowali dar, „na jaki się mogli zdobyćc79. W związku z tym mogło to być wotum żelazne lub srebrne, ale bardziej

\footnotetext{
74 Tamże, s. 168-169, 188-189, 225-229.

75 S.J. Kłossowski, Cuda y taski, s. 16, 18-19, 82, 123, 130-132, 241.

76 J.K. Steczewicz, Skarb Nieprzebrany, s. 168-169, 188-189, 225-229.

77 Tamże, s. 192.

78 Tamże, s. 147, 151, 225-229.

79 Tamże, s. 229.
} 
prawdopodobne są takie dary jak świeca z wosku, wieniec woskowy czy bryła wosku ${ }^{80}$. Dla porównania dodajmy, że w Prospekcie Wesolym (świadectwa od końca XVII w. do 1726 r.) wymieniono właśnie wota woskowe, które darowały osoby uboższe ${ }^{81}$. Poza tym dary z wosku czy woskowe wota były w omawianym okresie znamienne dla chłopów, a wspomniany Mateusz był właśnie przedstawicielem tej grupy ${ }^{82}$. Jacek Olędzki, Aleksandra Witkowska i Jowita Jagla zaobserwowali, że genezy tego zwyczaju należy szukać już w XV/XVI w. ${ }^{83}$ Zapytajmy jeszcze: czy w przypadku Mateusza w grę mogła wchodzić jakaś suma pieniędzy? Niestety, z Prospektu Wesotego dowiadujemy się, że dar dziękczynny w gotówce składały osoby zamożne ${ }^{84}$. Mateusz Ciemny nie był dobrze sytuowany, zatem sądzę, że tę formę podziękowania za ocalenie jego syna powinniśmy wykluczyć.

Czy w przypadku darów Władysława Kłodzińskiego i Anny Wieczorkowej również mieliśmy do czynienia z wotami woskowymi ${ }^{85}$ ? O ile Anna Wieczorkowa darowała być może takie wotum, o tyle Władysław Kłodziński jako podstoli dobrzyński raczej zaniósł wotum wykonane z jakiegoś kruszcu, np. ze srebra. Wszak wiadomo, że wota srebrne były znamienne dla sarmackiej kultury. Dodam też, że wspomniane przez J.K. Steczewicza wota wpisywały się w jeszcze jedną tendencję. Otóż od średniowiecza dokumentowano nasilenie pielgrzymek dziękczynnych, zatem nie dziwi większa ilość takich darów wotywnych ${ }^{86}$.

Osobno należy potraktować pytanie, kogo (lub co) wyobrażono na tych wotach? Przypuszczam, że raczej nie były to postaci dzieci. Z obserwacji Piotra Kowalskiego i J. Jagli wynikało, że tego rodzaju przedstawienie, dodajmy, że symbolizujące

80 A. Witkowska, Kulty pątnicze, s. 211; P. Kowalski, Prośba, s. 146; J. Jagla, Wieczna prośba $i$ dziękczynienie. O symbolicznych relacjach między „sacrum” $i$ „profanum” w przedstawieniach wotywnych z obszaru Polski Centralnej, Warszawa 2009, s. 81.

81 Surmatowski (ks.), Prospekt, s. 21, 36, 94, 150, 208.

82 J.K. Steczewicz, Skarb Nieprzebrany, s. 225; J. Olędzki, Wota woskowe ze wsi Brodowe Eąki i Krzynowtoga Wielka, Polska Sztuka Ludowa 14 (1960), nr 1, s. 3-5.

83 J. Olędzki, Wota woskowe, s. 5-6; A. Witkowska, Kulty pątnicze, s. 211; J.Jagla, Wieczna prośba, s. 81.

84 Surmatowski (ks.), Prospekt Wesoły, Miłosiernych Oczu, Przenayświętszey Maryi, Na smutne ludzkiey niedoli przypadki, z Gory S. Gostynskiey, taskawie obrocony. Albo zebranie cudow Przy Obrazie Nayświętszey Bogarodzice Panny przed Gostyniem doznanych, Poznań 1726, s. 91; por. M. Delimata-Proch, Choroby, s. 284.

85 J.K. Steczewicz, Skarb Nieprzebrany, s. 147, 151.

86 J. Olędzki, Wota srebrne, Polska Sztuka Ludowa 21 (1967), nr 2, s. 69; A. Witkowska, „Peregrinatio religiosa" w średniowiecznej Europie, [w:] Peregrinationes. Pielgrzymki w kulturze dawnej Europy, red. H. Manikowska, H. Zaremska, Warszawa 1995, s. 9-16, tu, s. 15; J. Jagla, Wieczna prośba, s. 84; por. J.S. Bystroń, Dzieje obyczajów w dawnej Polsce, t. 1, Warszawa 1976, s. 308 n. 
samo ocalone dziecko, dotyczyło dziękczynienia za łaskę uratowania noworodków i niemowląt ${ }^{87}$. Możemy potwierdzić ten wniosek, przywołując ponownie zbiór świadectw autorstwa S.J. Kłossowskiego. Opisano w nim wotum z wyobrażeniem dziecka, które darowała Elżbieta Kamińska, kapitanowa wojsk JKM. To wotum stanowiło podziękowanie za ocalenie właśnie nowonarodzonego dziecka ${ }^{88}$.

W Skarbie Nieprzebranym rzadziej mieliśmy do czynienia z takimi gestami dziękczynnymi jak: zanotowane ogłoszenie cudu, podziękowanie za łaskę oraz przystąpienie do spowiedzi i komunii świętej. Tę pierwszą formę wspomniano dwukrotnie, a dwa ostatnie gesty raz. Ogłoszenie cudu wiązało się z pielgrzymką i było tożsame z zeznaniem złożonym przed komisją. Niekiedy ogłoszenie cudu oznaczało także rozsławienie imienia Matki Bożej wśród okolicznej ludności, aby wierni udawali się do sanktuarium chętniej. Z takim wymiarem ogłoszenia cudu mieliśmy do czynienia w przypadku wielokrotnie już wspominanego syna Mateusza Ciemnego. J.K. Steczewicz zanotował, że rodzice zaraz po odnalezieniu syna „wysławiać Cuda Boskie i Najśw. Pannę poczęli”" Za to o samym zeznaniu wspomniano przy okazji relacji wdowy Reginy, której dziecko cierpiało na epilepsję ${ }^{90}$. Wyszczególnienie tej formy gestu dziwi, podobnie jak wspomniane odnotowanie w księdze pielgrzymki. Przecież każdy wotant miał obowiązek dać świadectwo doznanej łaski, choćby po to, aby zeznaniem złożonym przed komisją przyczynić się do uznania obrazu za cudotwórczy.

Co kryło się pod informacją o podziękowaniu za cud? Autor Skarbu Nieprzebranego wspomniał o takim geście, relacjonując zeznanie Jana Chojnackiego z Międzyrzecza, którego dziecko było śmiertelnie chore. Uważam, że słowa J.K. Steczewicza należy potraktować dosłownie tym bardziej, że Jan Chojnacki podziękował Matce Bożej, kiedy, „wróciwszy się do domu z Rokitna”, zastał dziecko zdrowe ${ }^{91}$. Za to żadnych wątpliwości nie wywołuje ostatni gest, czyli spowiedź i komunia święta, które odnajdujemy we wspomnianym zeznaniu wdowy Reginy, a które były połączone z pielgrzymką i daniem świadectwa ${ }^{92}$. Dla porównania z Prospektu Wesołego wynikało, że spowiedź i komunia często towarzyszyły właśnie złożeniu zeznania i czyniły go aktem bardziej podniosłym ${ }^{93}$.

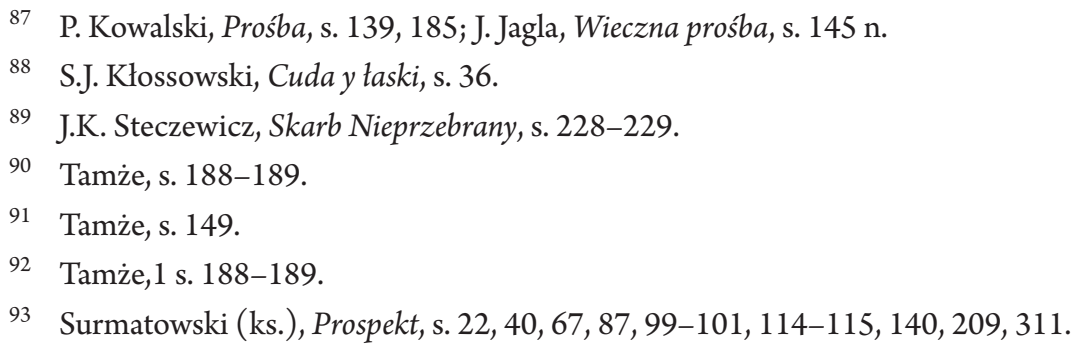


Na koniec przyjrzyjmy się jeszcze kwestii ewentualnych procedur medycznych. Czy J.K. Steczewicz odnotował jakieś zabiegi lub stosowanie medykamentów? W opisanych w księdze przypadkach dziecięcych spotykamy cztery odniesienia do „ziemskiego” ratunku. W dwóch ogólnikowo odnotowano bezradność, przy czym nie wspominano bezpośrednio o medykach czy cyrulikach, lecz po prostu stwierdzono, że rodzice na próżno szukali pomocy dla dziecka i tak: pani Korzeniewska wraz z mężem „mu [dziecku - M.D.P.] żadnego ratunku ani pomocy dać nie mogli”, a Katarzyna ze wsi Szarcz „radzi się rożnych ludzi, i prosi o poradę, i lekarstwo jakie, ale żadnego nie znajduje" 94 .

Wspomniane nawiązania do świata medycyny - bardzo mgliste w przypadku Korzeniewskich i wyraźniejsze w przypadku Katarzyny - miały także propagandowy wymiar. Chodziło po prostu o wskazanie, że najlepszym, najbardziej skutecznym lekarzem jest Opatrzność, która za pośrednictwem - w tym wypadku - Matki Bożej Rokitniańskiej oferuje pomoc w każdej beznadziejnej sytuacji. Nie inaczej należy interpretować słowa kapłana, który został wezwany do córeczki pewnej anonimowej kobiety. Kapłan, patrząc na ciężko chorą dziewczynkę, stwierdził, że jest ona „niepodobna środkami doczesnymi do uleczenia”, w związku z czym jej matka winna była polecić dziecko Bogu i Matce Bożej Rokitniańskiej95.

Analogiczny cel odnajdujemy w świadectwie ocalenia chłopca stratowanego przez konia, przy czym góruje ono nad pozostałymi zapiskami chociażby tym, że zasygnalizowano w niej udział cyrulika i kolejność postępowania w nagłych wypadkach. Z zapiski wynika, że chłopiec najpierw został zaniesiony właśnie do cyrulika, który podjął próby uratowania jego życia ${ }^{96}$. Miał on leczyć chłopca - niestety nie podano, jak długo - stosując różne smarowidła, maści ${ }^{97}$. Dopiero gdy stwierdzono, że jego działania

\footnotetext{
94 J.K. Steczewicz, Skarb Nieprzebrany, s. 153, 169.

95 Tamże, s. 154.
}

96 W tym świadectwie nie zanotowano flebotomii, podczas gdy ten zabieg bardzo chętnie stosowano przy urazach. Sekcje zwłok ujawniały, że w ciele osób zmarłych w nieszczęśliwych zdarzeniach było sporo skrzepłej krwi, w związku z czym, aby ocalić poszkodowanego należało dokonać upustu krwi, por. J. Węglorz, Zdrowie, s. 153 n. Za to odmiennie podchodzono do flebotomii w średniowieczu. Wtedy rozpowszechnione było przekonanie, że tego zabiegu nie wolno przeprowadzać na osobie osłabionej, szerzej na ten temat: B. Wojciechowska, Flebotomia i purgowanie, czyli o leczeniu w wiekach średnich, Kielce 2019, s. 15 n.

97 Nie będę spekulować, jaki był skład tych smarowideł. O najbardziej popularnych i stosowanych w tym okresie: W. Piotrowski, Medycyna polska, s. 71; B. Klukowska, Higiena dziecka, s. 313-351, tu, s. 348-351; K. Koper, Sposoby niesienia pomocy, s. 259-314, tu, s. 284-285, 293; J. Węglorz, Zdrowie, s. 179 n., 194 n. 
były nieefektywne, oddano chłopca pod opiekę Matki Bożej Rokitniańskiej ${ }^{98}$. Uzupełnię, że ujawniona bezradność cyrulika nie dziwi w kontekście rozpowszechnionego w XVII i XVIII w. przeświadczenia, zgodnie z którym szukanie pomocy u medyków jest w ogóle bezcelowe, ponieważ nie są oni skuteczni ${ }^{99}$. Z jednej strony ten brak skuteczności stanowil pochodną stopnia rozwoju wiedzy medycznej, z drugiej zaś niskich kompetencji polskich lekarzy, którzy niechętnie pogłębiali wiedzę ${ }^{100}$.

W Skarbie Nieprzebranym uderza niewielki odsetek przypadków dziecięcych związanych z ratunkiem od następstw nieszczęśliwych zdarzeń. Za to odnotowano więcej zapisek dotyczących uzdrowionych dzieci. Co ciekawe, w obu grupach brakuje świadectw przywrócenia życia, co prawdopodobnie wskazuje na szybką reakcję opiekunów szukających pomocy Opatrzności. Powtórzę raz jeszcze, że małą wartość poznawczą Skarbu Nieprzebranego w odniesieniu do jednostek chorobowych, danych personalnych dzieci, stosowanych terapii, udziału medyków należy tłumaczyć charakterem księgi jako zbioru zdarzeń mirakularnych. Przecież płeć lub wiek nie były tak naprawdę istotne. Liczyły się same świadectwa pielgrzymów, które dowodziły cudownego charakteru obrazu Pani z Rokitna. Z kolei opis mało efektywnego zaangażowania medyków służył jedynie podkreśleniu faktu, że najbardziej skutecznym lekarzem jest Opatrzność. Za to o kolejnym wymiarze księgi świadczyły zaobserwowane odwołania do symboliki biblijnej, wszak księga poza wymiarem dokumentalnym i propagandowym miała także charakter dydaktyczny. W związku z tym istotne było zapewnienie o nieuchronności, komplementarności i doskonałości łaski.

J.K. Steczewicz odsłonił szczątkowy świat emocji. Te wyrażały głównie matki, formułując autorskie modlitwy. Rozpacz czy lęk ojców był wzmiankowany, gdy była

98 J.K. Steczewicz, Skarb Nieprzebrany, s. 200-201.

99 Na ten temat wypowiedział się: J. Węglorz, Zdrowie, s. 222 n.; Christian Krötzl omówił to zagadnienie w odniesieniu do wieków wcześniejszych i w kontekście powszechnodziejowym: idem, Saints, Healing and Communities in the Later Middle Ages: On Roles and Perceptions, [w: ] Infirmity in Antiquity and the Middle Ages. Social and Cultural Approches to Health, Weakness and Care, eds C. Krötzl, K. Mustakallio, J. Kuuliala, London 2016, s. 255-264, tu, s. 260.

100 K. Rejmer, Zapomniana historia nauki. Panny apteczkowe, znachorzy, kottuny, Warszawa 2019, s. 113 n.; w XVII i XVIII w. w parze z niskimi kompetencjami lekarzy szła słaba ich dostępność: J. Kowalska, Personel medyczny miast królewskich Rzeczypospolitej w latach 1773-1792, [w: ] Wśród córek Eskulapa. Szkice z dziejów medycyny i higieny w Rzeczypospolitej XVI-XVIII wieku, red. A. Karpiński, cz. 2, Warszawa 2015, s. 315-368, tu, s. 341; por. M. Stawiak-Ososińska, Sztuka położnicza dla kobiet. Kształcenie akuszerek na ziemiach polskich $w$ dobie niewoli narodowej (1773-1914), Warszawa 2019, s. 38 n. 
mowa o reakcji obojga rodziców. W przypadku dzieci, których zdrowie i życie było zagrożone, prośby formułowali głównie rodzice i bardzo sporadycznie dalsi krewni np. dziadkowie. Same dzieci rzadko były wotantami, a te, które stawały przed obrazem, czy to błagając o łaskę, czy to dziękując za nią, doświadczały również terapeutycznego kontaktu z sacrum lub świadczyły własnym stanem o cudzie.

Wśród gestów proszalnych najczęstsze to prośby i modlitwy - w tym autorskie - oraz pielgrzymki. Za to sporadycznie spotykamy obietnicę peregrynacji, wotum, mszę świętą odprawioną w intencji dziecka czy prostrację. Również jeśli mówimy o gestach dziękczynnych, to najczęściej odnotowano peregrynację przed obraz, co dziwi, bo każdy uzdrowiony lub ocalony winien był wyznać, że doświadczył cudu, o czym wspominałam. Na drugim miejscu odnajdujemy wota, natomiast rzadziej złożenie zeznania, podziękowanie oraz przystąpienie do spowiedzi i komunii świętej.

$\mathrm{Na}$ koniec podkreślmy, jak istotne są badanie szczegółowe, które pozwalają uchwycić specyfikę poszczególnych ksiąg lub jej brak, a poza tym np. powszechność pewnych zjawisk w ramach religijności pielgrzymów. Jeśli mówimy o specyfice, to warto np. podkreślić, że u J.K. Steczewicza obserwujemy większy niż u innych autorów niedostatek danych personalnych pielgrzymów. Za to jeżeli mówimy o ogólnych tendencjach, to Skarb Nieprzebrany jest kolejną księgą, w której spotykamy nawiązania do biblijnej symboliki (cyfra trzy). Nie inaczej należy podejść do praktyk religijnych pielgrzymów. Problematyka gestów wotywnych wymaga wprawdzie dalszych studiów, ale już teraz możemy stwierdzić, że np. niektóre z nich nie tylko u J.K. Steczewicza występują łącznie (spowiedź i komunia święta towarzyszące wyznaniu łaski).

\section{Summary}

The author has touched upon several issues from the history of medicine by studying a book of miracles experienced by pilgrims in front of the picture of Our Lady of Rokitno (Skarb Nieprzebrany Dobrodziejstw Boskich. Obraz Cudowny Naświętszey Panny Mariey w Opactwie Bledzewskim Rokitnickiey by Jan Kazimierz Steczewicz). The article presents the issue of children's health, salvage from the risk of accidents and the assistance offered by physicians. What is more, the author presents the emotions of parents who found out about their children's poor condition. On the other hand, the bonds between parents and children or, more broadly, within a family or a local community show that various people took part in votive practices (supplicant's and thankful gestures). 
Prof. UAM dr hab. Małgorzata Delimata-Proch

Wydział Historii, Uniwersytet im. Adama Mickiewicza w Poznaniu

ul. Uniwersytetu Poznańskiego 7

61-614 Poznań

e-mail: greta@amu.edu.pl

Nadesłany 16 XI 2019

Nadesłany po poprawkach recenzyjnych 28 XII 2019

Zaakceptowany 8 I 2020 